\title{
DEVELOPMENT OF READY TO BAKE PLANT BASED CAKE MIXTURE FOR VEGETARIANS AND EGG ALLERGENS
}

\author{
PKGMP Aberathne ${ }^{1 *}$,SB Navaratne ${ }^{1}$, and I Wickramasinghe ${ }^{1}$ \\ ${ }^{1}$ Department of Food Science and Technology, Faculty of Applied Sciences, University of Sri Jaye- \\ wardenepura, Gangodawila, Nugegoda, Sri Lanka.
}

Accepted: $31^{\text {st }}$ August 2016

\begin{abstract}
A ready to bake cake mixture was developed using wheat, Sugar, coconut milk powder, baking powder, corn starch, xanthan gum, vanilla flavour and cream of tartar. Combination of corn starch, baking powder and xanthan gum were used as egg substitution. Eight samples were prepared and the best treatment was selected in terms of sensory properties. Proximate and shelf life analysis were carried out for the best treatment. The best treatment was organoleptically compared with vanilla flavoured cake. Results revealed that there was no significant difference between the two products in overall acceptability. Proximate analysis revealed that developed cake mixture having lower amount of protein and fat than the normal cake due to absence of egg and butter. Coconut milk powder was the only fat source which contributes around $16.74 \%$ fat into the final product. The shelf life analysis for the final product was carried out for two months by testing the sensory attributes, moisture content, peroxide value and microbial count under two types of packaging materials (Triple laminated and Polypropylene) as well as at two different temperatures $27^{\circ} \mathrm{C}$ (Ambient) and $4^{0} \mathrm{C}$ (Refrigerated). The sensory attributes along with microbiological level, moisture content and peroxides value of the sample packed in Polypropylene and kept under ambient temperature only had a significant deviation at the end of two months shelf life.
\end{abstract}

Key words: coconut milk powder, corn starch, cream of tartar, Polypropylene, Triple laminated and Xanthan gum

\section{INTRODUCTION}

Cake is a form of sweet that is typically baked. Cakes were modification of breads. Typical cake ingredients are wheat flour, sugar, eggs, butter or oil leaving agent and flavors. Eggs are used for most of the cake recipes in the world. Because of that most of vegetarians and some of egg allegiance cannot eat cake like desert prepared by adding eggs. High quality cakes can be characterized various attributes, including: high volume, uniform crumb softness and long shelf life due to tolerance to staling (Sakiyanet al., 2004).In cake processing, wheat flour, eggs, sugar and fat are the major ingredients. Eggs are the most costly ingredients and significant source of cholesterol. The use of partial or total substitution of egg in

*Corresponding author: mayurapkg@gmail.com cake formula, appears to be an interesting objective and especially for the people with specific dietary needs or restriction.

Expert estimate that as many as $1.5 \%$ of children are allergic to the egg. Vegetarians do not eat meat, fish, poultry and food products related to these sources. In recent years, a growing trend toward vegetarianism and veganism has arisen among young peoples and adults due to their increasing awareness of health, religious conviction, animal welfare and use of antibiotics and hormones in livestock (Phillip, 2005). Hence, along with the above conviction ready to bake cake mixture was developed with wholesome of plant base materials for vegetarians and egg allergens. 


\section{MATERIALS AND METHODS}

\section{Preparation of cake}

Powder form of all ingredients was used for the preparation of this cake mixture. After the weighted of ingredients, they were mixed well until form homogeneous mixture. Then mixture was sieved to remove the unwanted materials and large type of particles. Thereafter, $400 \mathrm{~g}$ of prepared flour mixture was put into bowl and $100 \mathrm{ml}$ of water was added into the mixture and mixed until to form a batter in suitable consistency. Prepared batter was put into a baking pan and placed in pre-heated oven $\left(190{ }^{0} \mathrm{C}\right)$ for 25 minutes. Finally baked cake was kept for 5 minute to cool down.

\section{Sensory evaluation}

Development cake was subjected to two sensory evaluations tests. First sensory evaluation was carried to select best cake flour mixture and second one was to compare the developed cake with normal vanilla (Commercial) flavor cake (with egg and butter). All samples were analyzed by a sensory panel for the sensory stimuli of color, texture, taste, mouth feel, odor and overall acceptability. The sensory panel consisted 30 numbers of semi-trained panelists.

Five point hedonic scale was used to rate the samples.

$\begin{array}{ll}\text { Extremely Like } & 5 \\ \text { Like } & 4 \\ \text { Neither like nor dislike } & 3 \\ \text { Dislike } & 2 \\ \text { Extremely Dislike } & 1\end{array}$

Results of the sensory evaluation were analyzed using the computer software Minitab. Non parametric ranking procedure with Kruskal Wallis test was used to analyze each parameter individually.

\section{Table 1. Variations of Cake Flour}

\begin{tabular}{lll}
\hline Variable & $\begin{array}{l}\text { Low } \\
\text { level }\end{array}$ & $\begin{array}{l}\text { High } \\
\text { Level }\end{array}$ \\
\hline $\begin{array}{l}\text { Coconut } \\
\text { milk }\end{array}$ & $15 \%$ & $20.5 \%$ \\
powder & & \\
$\begin{array}{l}\text { Baking } \\
\text { powder } \\
\text { Xanthan } \\
\text { gum }\end{array}$ & $1 \%$ & $1.5 \%$ \\
\hline
\end{tabular}

\section{Select best cake flour mixture}

To select best cake flour mixture, eight different cake formulations were prepared according to two factor factorial design while altering only three ingredients in the mixture namely coconut milk powder, xanthan gum and baking power. These three ingredients were kept at two levels "low and high" (Table 1) and eight treatment combinations were prepared as shown in table 2.

\section{Comparison of developed cake with normal- commercial vanilla flavor cake}

Three cake samples including normal vanilla flavored cake were named using three different digits. Sample No. 305 was contained only selected cake flour mixture and sample No. 410

\section{Table 2. Treatment Combination of Cake Flour Mixture}

\begin{tabular}{ccl}
\hline Treatment & Abbreviation & Treatment combinations \\
& & \\
\hline 370 & $\mathrm{a}_{1} \mathrm{~b}_{1} \mathrm{c}_{1}$ & $20.5 \%$ coconut milk powder, 1.5\% Baking powder, 0.1\% Xanthan gum \\
106 & $\mathrm{a}_{1} \mathrm{~b}_{1} \mathrm{c}_{0}$ & $20.5 \%$ coconut milk powder, 1.5\% Baking powder, 0.05\% Xanthan gum \\
450 & $\mathrm{a}_{1} \mathrm{~b}_{0} \mathrm{c}_{1}$ & $20.5 \%$ coconut milk powder, 1\% Baking powder, 0.1\% Xanthan gum \\
280 & $\mathrm{a}_{1} \mathrm{~b}_{0} \mathrm{c}_{0}$ & $20.5 \%$ coconut milk powder, $1 \%$ Baking powder, 0.05\% Xanthan gum \\
170 & $\mathrm{a}_{0} \mathrm{~b}_{1} \mathrm{c}_{1}$ & $15 \%$ coconut milk powder, $1.5 \%$ Baking powder, 0.1\% Xanthan gum \\
351 & $\mathrm{a}_{0} \mathrm{~b}_{1} \mathrm{c}_{0}$ & $15 \%$ coconut milk powder, $1.5 \%$ Baking powder, 0.05\% Xanthan gum \\
301 & $\mathrm{a}_{0} \mathrm{~b}_{0} \mathrm{c}_{1}$ & $15 \%$ coconut milk powder, $1 \%$ Baking powder, 0.1\% Xanthan gum \\
264 & $\mathrm{a}_{0} \mathrm{~b}_{0} \mathrm{c}_{0}$ & $15 \%$ coconut milk powder, 1\% Baking powder, 0.05\% Xanthan gum \\
\hline
\end{tabular}


contained selected cake flour mixture plus egg.

\section{Analysis of nutrition profile}

Nutrition profile was analyzed by using AOAC approved methods. For Crude Fiber Content (AOAC Method 978.10), Total F (AOAC Method 9922.06) Crude Protein Content (AOAC Method 960.52), Moisture Content (AOAC Method 925.10), Total Ash (AOAC Method 923.03).

Table 3. Formulation of developed cake mixture with normal cake

\begin{tabular}{cl}
\hline $\begin{array}{c}\text { Sample } \\
\text { number }\end{array}$ & \multicolumn{1}{c}{ Treatment } \\
\hline 230 & $\begin{array}{l}\text { Normal vanilla flavoured } \\
\text { cake }\end{array}$ \\
305 & $\begin{array}{l}\text { Developed cake flour mixture } \\
410\end{array}$ \\
& Developed cake flour mixture \\
& with eggs \\
\hline
\end{tabular}

\section{Analysis of shelf-life}

Samples were kept under four different test conditions as mention below with a view to determine how temperature and packaging material affect for the shelf-life of the prepared cake.

Triple laminated packaging with ambient temperature $\left(27^{\circ} \mathrm{C}\right)$

Triple laminated packaging with refrigerator condition $\left(4^{0} \mathrm{C}\right)$

Polypropylene packaging with ambient temperature $\left(27^{\circ} \mathrm{C}\right)$

Polypropylene packaging with refrigerator condition $\left(4^{0} \mathrm{C}\right)$

In determining of the shelf life of developed product, different test parameters such as sensory attributes, moisture content and yeast \&mould growth were utilized. Samples were tested for period of 2 months after packaging with two weeks intervals.

\section{RESULTS AND DISCUSSION}

Sensory properties of the eight cake samples

Sensory profiles of eight treatment combina- tions of cake pertaining to six sensory stimuli namely color, odor, texture, mouth feel and over all acceptability are shown in figure 1 .

According to the spider diagram given in figure 4.1, the samples with most preferred sensory attribute were sample $106 \&$ sample 450 . Sample 106 is the best among them. All the

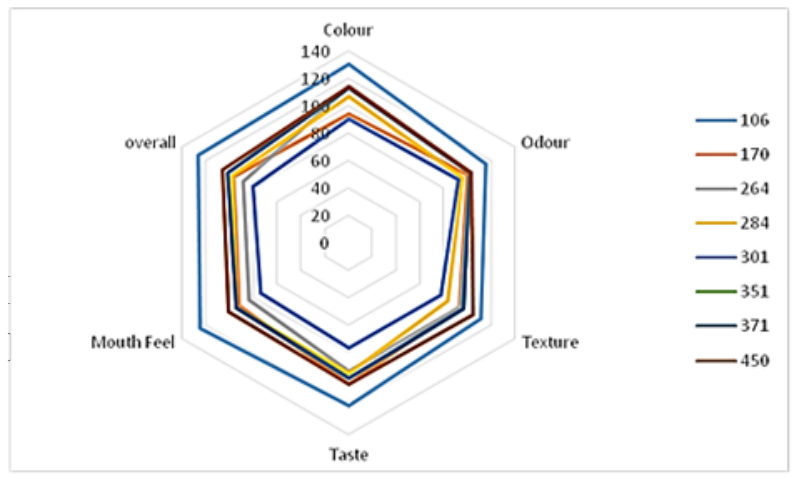

Figure 1. Spider web diagram for sensory profiles of eight cake samples

sensory attributes of the sample 106 according to Kruskall-Wallis statistical test method were significantly different $(0.05 \%<)$ than the other samples. Among the variable factors, high Coconut milk powder and baking powder and low xanthan gum is the best combination for this cake mixture.

Comparison of sensory properties of normal vanilla cake and two of developed cake

Sensory profiles of vanilla cake and cake prepared from treatment numbers 305 and 410 are giving in figure 2 .

According to the spider diagram in figure 2, there are some differences existed in sensory attributes of developed cake and normal vanilla flavoured cake. While vanilla cake has a good texture, other sensory properties are as not same as cake from developed two mixtures. However, Overall acceptability of twodeveloped cakes was as same as each other according to Kruskall- Wallis statistical test method $(0.05 \%<)$. 


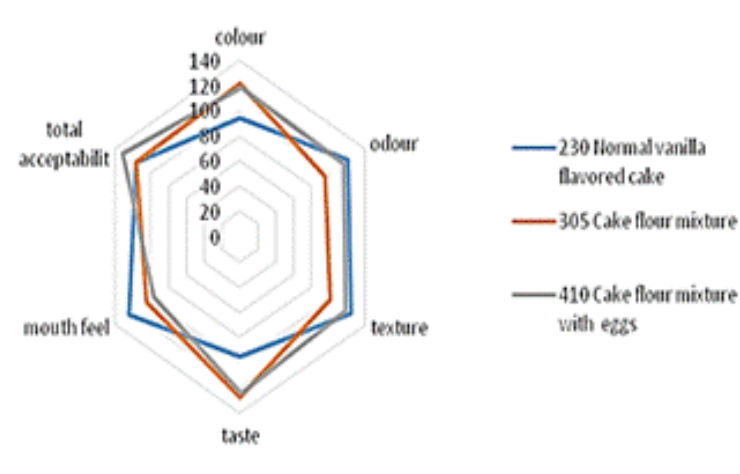

Figure 2. Sensory profiles of normal vanilla cake and developed cakes

\section{Proximate Analysis}

The data given in table 4 show the nutrient profile of the developed instant cake powder mixture.

According to the proximate analysis of developed Cake flour mixture (Table 4) moisture content was $6.13 \%$. Therefore, this cake mixture can be kept for a considerable period with a better moisture barrier packing material. Moisture content of flour is very important regarding its shelf life, lower the flour moisture, the better its storage stability. The deterioration of baking quality is also less at lower moisture content which can be credited to retarded respiration and activity of microorganisms (Staudt and Ziegler, 1973).

\section{Table 4. Nutritional Composition of Devel- oped Cake Mixture}

\begin{tabular}{ll}
\hline Nutrients & Percentage $(\mathrm{db})$ \\
\hline Moisture & $6.13 \pm 0.33$ \\
Crude Protein & $7.61 \pm 0.40$ \\
Total fat & $16.74 \pm 0.63$ \\
Ash & $1.27 \pm 0.12$ \\
Crude fiber & $2.12 \pm 0.21$ \\
Carbohydrates & $61.14 \pm 2.40$ \\
\hline
\end{tabular}

This mixture was developed without using eggs or other protein substitutes. Because of that protein content of the developed cake mixture was low $(7.61 \%)$. Ash content of the mixture was $1.27 \%$, it reflects high mineral content. Coconut milk powder and wheat flour mainly contribute to increase the mineral content of this mixture. Total carbohydrate content was high due to the presence of wheat flour, corn starch and sugar. Coconut milk powder also helps to give $16.74 \%$ fat content to the mixture.

\section{Determination of shelf life of the product: Analysis of variation of moisture content of cake mixtures}

Variation of moisture contents of cake mixtures packed and kept under 4 different conditions are showing in figure 3.

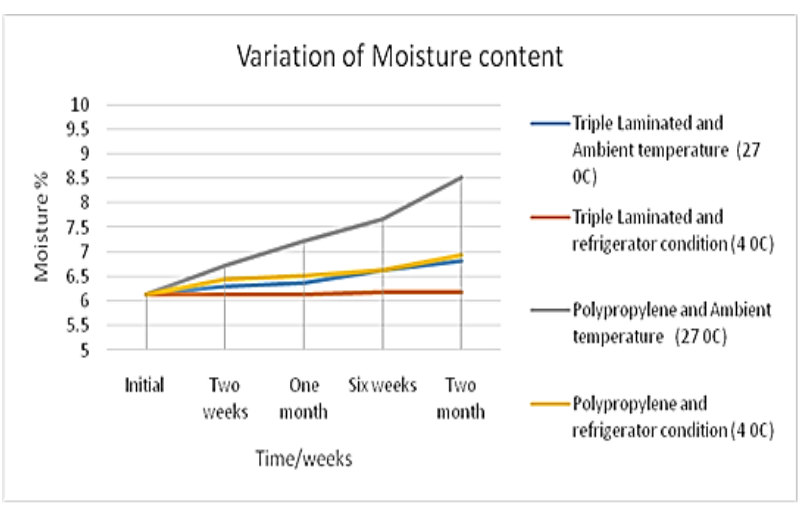

Figure 3. Variation of Moisture content

Water vapour transmission between food product and its surrounding environment is taking place at different intensities. Hence, selecting of an appropriate packing material for a hygroscopic food product is an important aspect in order to cope with the adverse consequences happening on the food product due to moisture migration. Moisture barrier property of the triple laminated packaging material is higher than polypropylene. Humidity level of the refrigerator is lower than ambient temperature. According to the figure 4.3 there was low moisture migration take place when products are packed in high moisture barrier packing materials (Triple laminate \& polypropylene) as well as kept under refrigerator condition. Because of that, both triple laminated and polypropylene can be used to pack this mixture if it is going to store under refrigerator condition. Further, this product 
can be stored in ambient temperature only with triple laminated packaging because; polypropylene is not suitable as it tends to ingress more water vapor into the product under conditions in the ambient temperature (27 $\left.{ }^{0} \mathrm{C}\right)$.

\section{Analysis of Peroxide Value}

Variations of peroxide values of cake mixture packed and kept under different conditions are given in table 5 .

The peroxide value (PV) is an indicator of the initial stages of oxidative change of fat. (Shahidi and Ying, 2005) According to the peroxide values given in table 6 , there was no detectable changes occurrence on peroxide value until end of the second month. Hence, it can be concluded that all the samples were safe from the oxidative rancidity for period of 2 month.

\section{Determination of Yeast and Mould growth}

Development of mould and yeast in the cake mixture are given in table 6 . The data given in table 6 clearly indicate that there was less yeast and mould count according to regulatory requirements at the end of the first month. Hence, all samples were suitable for consumption. Further, at the end of the second month there was an increase of yeast and mould count in the sample which was packed in polypropylene and kept under ambient temperature. The standards for cereal based products according to SLS-1998 for yeast and moulds are 102 and $104 \mathrm{CFU} / \mathrm{g}$. Thus, the result obtained from the study is not within acceptable range. Moreover, it can be stated that all other three products are safe to be consumed in terms of Yeasts and Moulds within two months time period except the product which was packed in polypropylene and kept under ambient temperature.

\section{Determination of Total plate count}

Total plate count $(\mathrm{CFU} / \mathrm{g})$ and corresponding shelf life of the developed cake mixes are given in Table 7.

The standards for cereal based products according to SLS for total plate count are $10^{5}$ and $10^{6} \mathrm{CFU} / \mathrm{g}$. According to the values given in

\section{Table 6. Yeast and Moulds count (CFU/g) on developed cake flour mixture against shelf life}

\begin{tabular}{lll}
\hline Treatment & $\mathbf{1}^{\text {st }}$ & $\mathbf{2}^{\text {nd }}$ \\
month & month \\
\hline $\begin{array}{l}\text { Triple Laminated and } \\
\text { Ambient temperature }\end{array}$ & 17 \\
$\begin{array}{l}\text { Triple Laminated and } \\
\text { refrigerator }\end{array}$ & 11 \\
condition $\left(4^{0} \mathrm{C}\right)$ & & \\
Polypropylene and 10 & $13 \times 10^{1}$ \\
$\begin{array}{l}\text { Ambient temperature } \\
\text { Polypropylene and } 12 \\
\text { refrigerator condition } \\
\left(4{ }^{0} \mathrm{C}\right)\end{array}$ & 14 \\
\hline
\end{tabular}

Table 5. Variation of Peroxide Value of Cake Mixture along with shelf life

\begin{tabular}{lllll}
\hline Condition & $\begin{array}{l}\text { Two } \\
\text { weeks }\end{array}$ & $\begin{array}{l}\text { One } \\
\text { month }\end{array}$ & Six weeks & $\begin{array}{l}\text { Two } \\
\text { months }\end{array}$ \\
\hline Triple Laminated and Ambient & Not & Not & Not & Not \\
temperature $\left(27^{\circ} \mathrm{C}\right)$ & Detected & Detected & Detected & Detected \\
Triple Laminated and & Not & Not & Not & Not \\
refrigerator condition $\left(4{ }^{\circ} \mathrm{C}\right)$ & Detected & Detected & Detected & Detected \\
Polypropylene and Ambient & Not & Not & Not & Not \\
temperature $\left(27^{\circ} \mathrm{C}\right)$ & Detected & Detected & Detected & Detected \\
Polypropylene and refrigerator & Not & Not & Not & Not \\
condition $\left(4^{\circ} \mathrm{C}\right)$ & Detected & Detected & Detected & Detected \\
\hline
\end{tabular}


Table 7 for total plate count, the results are within acceptable range in first two months. Therefore it can be concluded that all four products are safe to consume within the two months stipulated time period.

\section{CONCLUSION}

Developed instant cake mixture helps to reduce preparation time by more than $50 \%$ of

\section{Table 7. Total plate count of developed cake flour mix}

\begin{tabular}{lll}
\hline Treatment & $\begin{array}{l}\mathbf{1}^{\text {st }} \\
\text { month }\end{array}$ & $\begin{array}{l}\mathbf{2}^{\text {nd }} \\
\text { month }\end{array}$ \\
\hline $\begin{array}{l}\text { Triple } \\
\text { Laminated and }\end{array}$ & 13 & 34 \\
$\begin{array}{l}\text { Ambient } \\
\text { temperature }\end{array}$ & & \\
$\begin{array}{l}\text { Triple } \\
\text { Laminated and } \\
\text { refrigerator } \\
\text { condition( }\left({ }^{0} \mathrm{C}\right)\end{array}$ & 7 & 18 \\
$\begin{array}{l}\text { Polypropylene } \\
\text { and Ambient } \\
\text { temperature } \\
\text { Polypropylene } \\
\text { and refrigerator } \\
\text { condition }\left(4{ }^{\circ} \mathrm{C}\right)\end{array}$ & & \\
\hline
\end{tabular}

normal cake and simplify the cake making process by eliminating some steps. According to the proximate analysis, cake mixture had $16.74 \%$ fat. So coconut milk powder can be used as the fat source. By replacing egg and butter in this cake protein content was lower than that of normal cake.

When comparing the developed cake (without egg and butter) with normal vanilla flavored cake with egg, there was a different in the texture profile. In the case of developed cake, colour was better than the normal cake and there was very little taste different due to the presence of coconut milk powder. According to the sensory evaluation, taste and color of this cake were acceptable as same as normal cake.
According to the shelf-life evaluation test, triple laminated packing material was the most suitable packaging material. Further, the mixture can be kept for two month without any significant changes under refrigerator $\left(4^{0} \mathrm{C}\right)$ or ambient temperature $\left(27{ }^{0} \mathrm{C}\right)$ condition. Because there was no significant different in moisture content, microorganism level and other organoleptic properties when compare to the initial sample. Therefore it can be concluded that this products is safe to consumer for two months from the date of manufacture.

\section{REFERENCE}

Phillips, F. (2005) 'Vegetarian nutrition' British Nutrition Foundation Nutrition Bulletin, 30, 132-167

Sakiyan, O., Sumnu, G., Sahin, S. and Bayram, G. (2004) 'Influence of fat content and emulsifier type on the rheological properties of cake batter' Eur. Food Res. Technol. 219: 635-638.

Shahidi, F. and Ying Zhong, 2005. Lipid oxidation: measurement methods in: Bailey's Industrial Oil and Fat Products, Sixth Edition, Edited by FereidoonShahidi, John Wiley \& Sons, Inc. PP 357385

Sri Lanka Standards Institution, Sri Lanka Standards, Specifications for Cereal based products, SLS 1179: 1998.

Staudt, E. and Ziegler. 1973. Flour Chemistry, $1^{\text {st }}$ ED. Bhuler Brothers Ltd., Engineering works 9240 Uzwil, Switzerland.

Yang, X. and Foegeding, F.A., (2010) 'Effects of sucrose on egg white protein and whey protein isolate foams: Factors determining properties of wet and dry foams (cakes)'. Food Hydrocolloid 24: 227-238. 